Article

\title{
Analysis of Altmetrics in Social Recognition of Neurology and Neurological Disorders
}

\author{
Yerim Kim ${ }^{1}{ }^{\mathbb{D}}$, Jee-Eun Kim ${ }^{2}$, Sang-Hwa Lee ${ }^{3}$, Dae Young Yoon ${ }^{4}$ and Jong Seok Bae ${ }^{1, *}$ \\ 1 Department of Neurology, Kangdong Sacred Heart Hospital, Hallym University College of Medicine, \\ Seoul 05355, Korea; brainyrk@hallym.ac.kr \\ 2 Department of Neurology, Ewha Womans University Seoul Hospital, Seoul 07804, Korea; junenr@gmail.com \\ 3 Department of Neurology, Chuncheon Sacred Heart Hospital, Hallym University College of Medicine, \\ Chuncheon 24253, Korea; neurolsh@hallym.or.kr \\ 4 Department of Radiology, Kangdong Sacred Heart Hospital, Hallym University College of Medicine, \\ Seoul 05355, Korea; daeyoung@kdh.or.kr \\ * Correspondence: jongseokbae@kdh.or.kr; Tel.: +82-10-2224-2206
}

Received: 1 September 2020; Accepted: 23 September 2020; Published: 25 September 2020

\begin{abstract}
This study used Altmetric analysis to rank neurological articles and assessed the implications in relation to the social recognition of neurology and neurological disorders. An Altmetric Explorer search was conducted on 25 May 2018 for articles published in the 91 journals included in the 2015 InCites ${ }^{\mathrm{TM}}$ Journal Citation Report ${ }^{\circledR}$. We identified and analyzed the 100 articles with the highest Altmetric Attention Scores (AASs). A major proportion of the social impact (high AASs) was focused on neurodegenerative disorders such as dementia and neurodegenerative disorders. About half of the high-ranking articles provided academic information such as disease information ( 29 articles, $29 \%)$, new or advanced treatments $(17 \%)$, and side effects of treatment $(8 \%)$. The journal with largest number of top 100 articles was the New England Journal of Medicine ( 29 articles). Some of the data gathered via altmetrics can change a field of study, the public's health, or a larger society. This is the first report on the impact of academic articles in neurological disorder on the general public living in our altered information society.
\end{abstract}

Keywords: neurology; neurodegenerative diseases; public health informatics; attention; social networking

\section{Introduction}

The impact of research articles has traditionally been measured and graded mainly based on the frequency and the numbers of citations during a certain period. Bibliometric analysis utilizing this approach can quantitatively measure the academic influence and the impact of researchers. However, this technique involves a considerable amount of time to have lapsed after articles are published [1]. In addition, certain types of bibliometric analysis have disclosed that specific academic trends or popular issues may contribute to articles being ranked highly [2]. Another crucial issue to consider is that bibliometrics does not reflect the impact of articles on the general public.

The acquisition of medical information is changing markedly with the increasing popularity of the internet. This means that many people are nowadays exposed to medical news from mass communication and social network systems as well as from academic articles written by specialists [3,4]. For example, online platforms such as Twitter, blogs, and online sites of community addressing medical information can rapidly disseminate new information and academic outcomes related to medical science. It is therefore reasonable to assume that this changing environment will alter attitudes toward learning about new medical information. 
Several tools have been developed to address the impact of this new communication environment [5-7]. Altmetric analysis is one such commonly available tool and is now being used by some influential medical journals for measuring the social impact of their publications. Altmetrics is a term that has been used in the literature to refer to both article-level and alternative metrics. It can measure and visualize the impact of research articles on various new online platforms [8]. Therefore, Altmetric analysis can be used to estimate the dissemination of medical information related to certain research articles.

Neurology is a specialty of clinical medicine that covers numerous subspecialties such as dementia, stroke, epilepsy, demyelinating disorders, parkinsonism, and neuromuscular disorders. These disorders have been among the most popular subjects of investigation in neuroscience research, and many basic research studies related to these diseases are ongoing, which is rapidly improving the understanding of the basic mechanisms underlying the diseases. Neurologists across all subspecialties also perform clinical research based on advances in basic research, and some of their outcomes have been drawn to the attention of the general public thanks to them being highlighted in the mass media. The aim of this study was to determine which recent papers in the field of neurology have received the highest Altmetric Attention Scores (AASs). This study analyzed the highly ranked articles in the fields of neurology and neurological disorders as identified using Altmetric analysis and evaluated the implications of this technique in terms of the recognition of neurology and neurological disorders among the general public.

\section{Materials and Methods}

\subsection{Study Design and Setting}

The web-based application Altmetric Explorer (Altmetric, London, UK) was utilized as a search engine in this study. The results were visualized using the Altmetric donut, which is a multicolored circle that displays the relative contributions of all sources. This donut symbolizes the dissemination of research output via different sources (Facebook, Twitter, Google+, Linked In, Sina Weibo, and Pinterest), and the display format demonstrates a weighted score. The Altmetric Attention Score (AAS) is presented in the center of the graphic. Detailed information about the algorithm and examples of its application are available elsewhere [6,9].

An Altmetric Explorer search was conducted on 25 May 2018 for articles published in the 91 journals included in the 2015 InCites $^{\mathrm{TM}}$ Journal Citation Report ${ }^{\circledR}$ grouped under the subject categories of clinical neurology, neuroscience, and general and internal medicine. The site was accessed on only a single specific day (25 May 2018) to avoid changes in the online presentation of articles interfering with the analyses. No restrictions were applied regarding language, date of publication, AAS, keywords, title of output, type of output, or scholarly identifiers.

Data cannot be shared because there are embargoes on datasets. Anonymized data will be shared by request from any qualified investigator.

\subsection{Data Sources}

We analyzed the full text of the 100 articles with the top AASs and extracted detailed information about title, year of publication, AAS, corresponding author, journal name, and journal impact factor (based on the 2017 science edition). Because of considerable subject overlap between articles in the clinical neurology and the neuroscience fields, the authors first analyzed clinical neurology journals and thereafter included additional articles in neuroscience journals that provided clear information regarding neurological disorders. We also analyzed the articles in general and internal medicine journals that focused on neurological disorders as the main subject. After selecting 100 articles, we categorized them into 15 subspecialties of disease groups and 5 categories of main subjects.

Two neurologists (Yerim Kim. and Jong Seok Bae) independently identified and analyzed the articles. In cases of disagreement between these two reviewers, consensus was achieved 
through open discussions. The present study adopted a descriptive research approach by means of bibliometric analysis.

\subsection{Standard Protocol Approvals, Registrations, and Patient Consents}

The present study did not involve human subjects and thus did not require approval from an institutional review board. We used STROBE guidelines for a descriptive study [10].

\section{Results}

We finally selected the 100 articles with the highest AASs (range $=868-3873$ ), as listed in Table 1. The journal with largest number of top 100 article was the New England Journal of Medicine (29 articles), while the Neurology journal had the largest number of articles in the field of clinical neurology (13 articles). We investigated the type of access because they can also affect the accessibility of social media (Table 2). The most common author nationality was American (Table 3). In cases of a co-corresponding author, the nationality of the first author was listed.

Regarding the disease category or subspecialty, social recognition was relatively concentrated on degenerative disorders and cerebrovascular disorders. Research articles in the neuroscience field providing advanced information about disease mechanisms had the second highest ranks (Table 4). A particularly interesting finding was that most of the articles classified in the neuroscience field also contained subjects related to cognitive and behavioral science (e.g., memory, addiction, and intelligence). These findings suggest that dementia and cognitive/neurobehavioral problems receive more attention from the general public.

We arbitrarily categorized the articles in the following five subjects based on interest in health and medical services among the general public: disease information, lifestyle and disease, science information, new or advanced treatments, and side effects of treatment. As indicated in Table 5, the ranking order of subject categories was identical to the order in the above list. About half of the high-rank articles provided medical information such as disease information ( 29 articles, 29\%), new or advanced treatments $(17 \%)$, and side effects of treatment $(8 \%)$. However, half of the 100 articles were about less academic subjects, with 27 articles (27\%) addressing the relationship between lifestyle and diseases. 
Table 1. Top 100 articles with the highest Altmetric Attention Scores (AASs).

\begin{tabular}{|c|c|c|c|c|c|}
\hline Rank & Article Title & AAS & Journal & Corresponding Author & Country \\
\hline 1 & The terrorist inside my husband's brain & 3873 & Neurology & Susan Schneider Williams & USA \\
\hline 2 & $\begin{array}{c}\text { Clinicopathological evaluation of chronic traumatic encephalopathy in } \\
\text { players of American football }\end{array}$ & 3674 & $\begin{array}{l}\text { JAMA: Journal of the American } \\
\text { Medical Association }\end{array}$ & Ann C. McKee & USA \\
\hline 3 & Dementia prevention, intervention, and care & 3294 & The Lancet & Gill Livingston & UK \\
\hline 4 & $\begin{array}{l}\text { Moderate alcohol consumption as risk factor for adverse brain outcomes } \\
\text { and cognitive decline: longitudinal cohort study }\end{array}$ & 3222 & British Medical Journal & Anya Topiwala & UK \\
\hline 5 & $\begin{array}{c}\text { Sugar- and artificially sweetened beverages and the risks of incident stroke } \\
\text { and dementia }\end{array}$ & 3215 & Stroke & Matthew P. Pase & USA \\
\hline 6 & $\begin{array}{l}\text { Living near major roads and the incidence of dementia, Parkinson's } \\
\text { disease, and multiple sclerosis: a population-based cohort study }\end{array}$ & 2924 & The Lancet & Hong Chen & Canada \\
\hline 7 & Neurobehavioral effects of developmental toxicity & 2870 & Lancet Neurology & Philippe Grandjean & USA \\
\hline 8 & $\begin{array}{c}\text { Nutrients and bioactives in green leafy vegetables and cognitive decline: } \\
\text { prospective study }\end{array}$ & 2538 & Neurology & Martha Clare Morris & USA \\
\hline 9 & Trial of cannabidiol for drug-resistant seizures in the Dravet syndrome & 2516 & $\begin{array}{l}\text { New England Journal of } \\
\text { Medicine }\end{array}$ & Orrin Devinsky & USA \\
\hline 10 & Zika virus associated with microcephaly & 2400 & $\begin{array}{l}\text { New England Journal of } \\
\text { Medicine }\end{array}$ & Tatjana Avšič Županc & Slovenia \\
\hline 11 & Were James Bond's drinks shaken because of alcohol induced tremor? & 2249 & British Medical Journal & Patrick Davies & UK \\
\hline 12 & $\begin{array}{l}\text { Guillain-Barré Syndrome outbreak associated with Zika virus infection in } \\
\text { French Polynesia: a case-control study }\end{array}$ & 2202 & The Lancet & Arnaud Fontanet & $\begin{array}{l}\text { Francench } \\
\text { Polynesia }\end{array}$ \\
\hline 13 & $\begin{array}{l}\text { Post-study caffeine administration enhances memory consolidation } \\
\text { in humans }\end{array}$ & 2202 & Nature Neuroscience & Michael A. Yassa & USA \\
\hline 14 & $\begin{array}{l}\text { Association between dietary factors and mortality from heart disease, } \\
\text { stroke, and type } 2 \text { diabetes in the United States }\end{array}$ & 2190 & $\begin{array}{l}\text { JAMA: Journal of the American } \\
\text { Medical Association }\end{array}$ & Renata Micha & USA \\
\hline 15 & $\begin{array}{l}\text { Long working hours and risk of coronary heart disease and stroke: a } \\
\text { systematic review and meta-analysis of published and unpublished data } \\
\text { for 603,838 individuals }\end{array}$ & 2016 & The Lancet & Mika Kivimäki & UK \\
\hline 16 & $\begin{array}{c}\text { Thrombectomy } 6 \text { to } 24 \mathrm{~h} \text { after stroke with a mismatch between deficit } \\
\text { and infarct }\end{array}$ & 1591 & $\begin{array}{l}\text { New England Journal of } \\
\text { Medicine }\end{array}$ & Tudor G. Jovin & USA \\
\hline 17 & $\begin{array}{l}\text { Concussion, microvascular injury, and early tauopathy in young athletes } \\
\text { after impact head injury and an impact concussion mouse model }\end{array}$ & 1563 & Brain & Lee E. Goldstein & USA \\
\hline 18 & Incidence of dementia over three decades in the Framingham Heart Study & 1544 & $\begin{array}{l}\text { New England Journal of } \\
\text { Medicine }\end{array}$ & Sudha Seshadri & USA \\
\hline
\end{tabular}


Table 1. Cont

\begin{tabular}{|c|c|c|c|c|c|}
\hline Rank & Article Title & AAS & Journal & Corresponding Author & Country \\
\hline 19 & $\begin{array}{l}\text { Zika virus infection with prolonged maternal viremia and fetal } \\
\text { brain abnormalities }\end{array}$ & 1537 & $\begin{array}{l}\text { New England Journal of } \\
\text { Medicine }\end{array}$ & $\begin{array}{l}\text { Rita W. Driggers } \\
\text { Adre du Plessis } \\
\text { Olli Vapalahti }\end{array}$ & $\begin{array}{l}\text { USA } \\
\text { Finland } \\
\text { Finland }\end{array}$ \\
\hline 20 & $\begin{array}{l}\text { Mixed pathologies including chronic traumatic encephalopathy account for } \\
\text { dementia in retired association football (soccer) players }\end{array}$ & 1532 & Acta Neuropathologica & $\begin{array}{l}\text { Janice L. Holton } \\
\text { Tamas ReveszTamas } \\
\text { Revesz }\end{array}$ & $\begin{array}{l}\text { UK } \\
\text { UK }\end{array}$ \\
\hline 21 & Obesity associated with increased brain age from midlife & 1491 & Neurobiology of Aging & Lisa Ronan & UK \\
\hline 21 & Mnemonic training reshapes brain networks to support superior memory & 1491 & Neuron & Martin Dresler & $\begin{array}{l}\text { The } \\
\text { Netherlands }\end{array}$ \\
\hline 23 & $\begin{array}{c}\text { Mediterranean diet and age-related cognitive decline: a randomized } \\
\text { clinical trial }\end{array}$ & 1486 & JAMA Internal Medicine & Emilio Ros & Spain \\
\hline 24 & $\begin{array}{c}\text { Mediterranean-type diet and brain structural change from } 73 \text { to } 76 \text { years in } \\
\text { a Scottish cohort }\end{array}$ & 1471 & Neurology & Michelle Luciano & UK \\
\hline 25 & $\begin{array}{l}\text { Association of proton pump inhibitors with risk of dementia: a } \\
\text { pharmacoepidemiological claims data analysis }\end{array}$ & 1458 & JAMA Neurology & Britta Haenisch & Germany \\
\hline 26 & Thrombectomy for stroke at 6 to $16 \mathrm{~h}$ with selection by perfusion imaging & 1426 & $\begin{array}{l}\text { New England Journal of } \\
\text { Medicine }\end{array}$ & Gregory W. Albers & USA \\
\hline 27 & $\begin{array}{l}\text { Restoration of reaching and grasping movements through brain-controlled } \\
\text { muscle stimulation in a person with tetraplegia: a proof-of-concept } \\
\text { demonstration }\end{array}$ & 1403 & The Lancet & A. Bolu Ajiboye & USA \\
\hline 28 & A controlled trial of erenumab for episodic migraine & 1378 & $\begin{array}{l}\text { New England Journal of } \\
\text { Medicine }\end{array}$ & Peter J. Goadsby & UK \\
\hline 29 & $\begin{array}{c}\text { Dutch courage? Effects of acute alcohol consumption on self-ratings and } \\
\text { observer ratings of foreign language skills }\end{array}$ & 1350 & Journal of Psychopharmacology & Fritz Renner & $\begin{array}{l}\text { The } \\
\text { Netherlands }\end{array}$ \\
\hline 30 & Fully implanted brain-computer interface in a locked-in patient with ALS & 1333 & $\begin{array}{l}\text { New England Journal of } \\
\text { Medicine }\end{array}$ & Nick F. Ramsey & $\begin{array}{l}\text { The } \\
\text { Netherlands }\end{array}$ \\
\hline 31 & $\begin{array}{c}\text { Alzheimer's disease drug-development pipeline: few candidates, } \\
\text { frequent failures }\end{array}$ & 1281 & Alzheimer's Research \& Therapy & Jeffrey L. Cummings & USA \\
\hline 32 & $\begin{array}{l}\text { Alcohol acutely enhances decoding of positive emotions and emotional } \\
\text { concern for positive stimuli and facilitates the viewing of sexual images }\end{array}$ & 1271 & Psychopharmacology & Matthias E. Liechti & Switzerland \\
\hline 33 & Regression of glioblastoma after chimeric antigen receptor T-cell therapy & 1252 & $\begin{array}{l}\text { New England Journal of } \\
\text { Medicine }\end{array}$ & Behnam Badie & USA \\
\hline
\end{tabular}


Table 1. Cont

\begin{tabular}{|c|c|c|c|c|c|}
\hline Rank & Article Title & AAS & Journal & Corresponding Author & Country \\
\hline 34 & $\begin{array}{l}\text { Clinical features and neuroimaging (CT and MRI) findings in presumed } \\
\text { Zika virus related congenital infection and microcephaly: retrospective } \\
\text { case series study }\end{array}$ & 1249 & British Medical Journal & $\begin{array}{l}\text { Maria de Fatima Vasco } \\
\text { Aragao }\end{array}$ & Brazil \\
\hline 35 & Nuclear receptor NR1H3 in familial multiple sclerosis & 1226 & Neuron & $\begin{array}{l}\text { Weihong Song } \\
\text { Carles Vilariño-Güell }\end{array}$ & $\begin{array}{l}\text { Canada } \\
\text { Canada }\end{array}$ \\
\hline 36 & Zika and the risk of microcephaly & 1225 & $\begin{array}{l}\text { New England Journal of } \\
\text { Medicine }\end{array}$ & Michael A. Johansson & USA \\
\hline 37 & Single-dose gene-replacement therapy for spinal muscular atrophy & 1222 & $\begin{array}{l}\text { New England Journal of } \\
\text { Medicine }\end{array}$ & Jerry R. Mendell & USA \\
\hline 38 & $\begin{array}{l}\text { Enhancing dentate gyrus function with dietary flavanols improves } \\
\text { cognition in older adults }\end{array}$ & 1218 & Nature Neuroscience & Scott A. Small & USA \\
\hline 38 & $\begin{array}{l}\text { Surface-based morphometry reveals the neuroanatomical basis of the } \\
\text { five-factor model of personality }\end{array}$ & 1218 & $\begin{array}{l}\text { Social Cognitive \& Affective } \\
\text { Neuroscience }\end{array}$ & Luca Passamonti & UK \\
\hline 40 & $\begin{array}{l}\text { Bilingualism delays age at onset of dementia, independent of education } \\
\text { and immigration status }\end{array}$ & 1209 & Neurology & Suvarna Alladi & India \\
\hline 41 & Hematopoietic stem-cell gene therapy for cerebral adrenoleukodystrophy & 1190 & $\begin{array}{l}\text { New England Journal of } \\
\text { Medicine }\end{array}$ & David A. Williams & USA \\
\hline 42 & $\begin{array}{c}\text { Circadian rest-activity pattern changes in aging and preclinical } \\
\text { Alzheimer disease }\end{array}$ & 1183 & JAMA Neurology & Yo-El S. Ju & USA \\
\hline 43 & Cannabinoids for epilepsy—real data, at last & 1171 & $\begin{array}{l}\text { New England Journal of } \\
\text { Medicine }\end{array}$ & Samuel F. Berkovic & Australia \\
\hline 44 & $\begin{array}{l}\text { Association of playing high school football with cognition and mental } \\
\text { health later in life }\end{array}$ & 1153 & JAMA Neurology & Dylan S. Small & USA \\
\hline 45 & Migraine and vascular disease & 1131 & British Medical Journal & Rebecca C. Burch & USA \\
\hline 46 & Emotional brain states carry over and enhance future memory formation & 1123 & Nature Neuroscience & Lila Davachi & USA \\
\hline 47 & $\begin{array}{l}\text { What paint can tell us: a fractal analysis of neurological changes in } \\
\text { seven artists }\end{array}$ & 1113 & Neuropsychology & Alex Forsythe & UK \\
\hline 48 & $\begin{array}{c}\begin{array}{c}\text { Evidence of amyloid- } \beta \text { cerebral amyloid angiopathy transmission through } \\
\text { neurosurgery }\end{array}\end{array}$ & 1097 & Acta Neuropathologica & Sebastian Brandner & UK \\
\hline 49 & Neurobiologic advances from the brain disease model of addiction & 1092 & $\begin{array}{l}\text { New England Journal of } \\
\text { Medicine }\end{array}$ & Nora D. Volkow & USA \\
\hline 50 & Zika virus associated with meningoencephalitis & 1082 & $\begin{array}{l}\text { New England Journal of } \\
\text { Medicine }\end{array}$ & Guillaume Carteaux & France \\
\hline
\end{tabular}


Table 1. Cont

\begin{tabular}{|c|c|c|c|c|c|}
\hline Rank & Article Title & AAS & Journal & Corresponding Author & Country \\
\hline 51 & $\begin{array}{c}\text { Age-specific risks, severity, time course, and outcome of bleeding on } \\
\text { long-term antiplatelet treatment after vascular events: a population-based } \\
\text { cohort study }\end{array}$ & 1081 & The Lancet & $\begin{array}{l}\text { Peter M. Rothwell } \\
\text { FMedSci }\end{array}$ & UK \\
\hline 52 & $\begin{array}{l}\text { Evidence for sugar addiction: behavioral and neurochemical effects of } \\
\text { intermittent, excessive sugar intake }\end{array}$ & 1077 & $\begin{array}{l}\text { Neuroscience \& Biobehavioral } \\
\text { Reviews }\end{array}$ & Bartley G. Hoebel & USA \\
\hline 53 & MIND diet associated with reduced incidence of Alzheimer's disease & 1074 & Alzheimer's \& Dementia & Martha Clare Morris & USA \\
\hline 54 & The neural correlates of dreaming & 1070 & Nature Neuroscience & Giulio Tononi & USA \\
\hline 55 & Trial of amitriptyline, topiramate, and placebo for pediatric migraine & 1069 & $\begin{array}{l}\text { New England Journal of } \\
\text { Medicine }\end{array}$ & Scott W. Powers & USA \\
\hline 56 & $\begin{array}{l}\text { The feasibility of a brain-computer interface functional electrical } \\
\text { stimulation system for the restoration of overground walking } \\
\text { after paraplegia }\end{array}$ & 1062 & $\begin{array}{l}\text { Journal of NeuroEngineering and } \\
\text { Rehabilitation }\end{array}$ & $\begin{array}{c}\text { An H. Do } \\
\text { Zoran Nenadic }\end{array}$ & $\begin{array}{l}\text { USA } \\
\text { USA }\end{array}$ \\
\hline 57 & $\begin{array}{l}2018 \text { Guidelines for the Early Management of Patients with Acute Ischemic } \\
\text { Stroke: a guideline for healthcare professionals from the American Heart } \\
\text { Association/American Stroke Association }\end{array}$ & 1061 & Stroke & $\begin{array}{l}\text { the American Heart } \\
\text { Association Stroke } \\
\text { Council }\end{array}$ & USA \\
\hline 58 & The persistence and transience of memory & 1049 & Neuron & Paul W. Frankland & Canada \\
\hline 59 & Meditation experience is associated with increased cortical thickness & 1042 & NeuroReport & Sara W. Lazar & USA \\
\hline 60 & $\begin{array}{l}\text { Practice guideline update summary: Mild cognitive impairment: Report of } \\
\text { the Guideline Development, Dissemination, and Implementation } \\
\text { Subcommittee of the American Academy of Neurology }\end{array}$ & 1038 & Neurology & $\begin{array}{l}\text { American Academy of } \\
\text { Neurology }\end{array}$ & USA \\
\hline 61 & Glucose levels and risk of dementia & 1020 & $\begin{array}{l}\text { New England Journal of } \\
\text { Medicine }\end{array}$ & Paul K. Crane & USA \\
\hline 62 & $\begin{array}{c}\text { Does playing violent video games cause aggression? A longitudinal } \\
\text { intervention study }\end{array}$ & 1017 & Molecular Psychiatry & Simone Kühn & Germany \\
\hline 63 & $\begin{array}{c}\text { Changes in sleep duration, quality, and medication use are prospectively } \\
\text { associated with health and well-being: analysis of the UK Household } \\
\text { Longitudinal Study }\end{array}$ & 1000 & Sleep & Nicole K. Y. Tang & UK \\
\hline 64 & Vitamin D and the risk of dementia and Alzheimer disease & 989 & Neurology & David J. Llewellyn & UK \\
\hline 65 & Ocrelizumab versus placebo in primary progressive multiple sclerosis & 975 & $\begin{array}{l}\text { New England Journal of } \\
\text { Medicine }\end{array}$ & Xavier Montalban & Spain \\
\hline 66 & The busier the better: greater busyness is associated with better cognition & 958 & Frontiers in Aging Neuroscience & Sara B. Festini & USA \\
\hline 67 & Hearing loss and cognitive decline in older adults & 956 & JAMA Internal Medicine & Frank R. Lin & USA \\
\hline
\end{tabular}


Table 1. Cont

\begin{tabular}{|c|c|c|c|c|c|}
\hline Rank & Article Title & AAS & Journal & Corresponding Author & Country \\
\hline 67 & Anxiety cells in a hippocampal-hypothalamic circuit & 956 & Neuron & $\begin{array}{l}\text { Mazen A. Kheirbek } \\
\text { René Hen }\end{array}$ & $\begin{array}{l}\text { USA } \\
\text { USA }\end{array}$ \\
\hline 69 & $\begin{array}{l}\text { Midlife cardiovascular fitness and dementia: a 44-year longitudinal } \\
\text { population study in women }\end{array}$ & 954 & Neurology & Helena Hörder & Sweden \\
\hline 70 & $\begin{array}{c}\text { Time to wake up and smell the coffee? Coffee consumption and } \\
\text { multiple sclerosis }\end{array}$ & 951 & $\begin{array}{l}\text { Journal of Neurology, } \\
\text { Neurosurgery \& Psychiatry }\end{array}$ & Elaine Kingwell & Canada \\
\hline 71 & $\begin{array}{c}\text { Alcohol intake and cognitively healthy longevity in community-dwelling } \\
\text { adults: the Rancho Bernardo Study }\end{array}$ & 950 & Journal of Alzheimer's Disease & Erin Richard & USA \\
\hline 72 & $\begin{array}{c}\text { Glioproliferative lesion of the spinal cord as a complication of "stem-cell } \\
\text { tourism" }\end{array}$ & 949 & $\begin{array}{l}\text { New England Journal of } \\
\text { Medicine }\end{array}$ & $\begin{array}{l}\text { Aaron L. Berkowitz } \\
\text { Michael B. Miller }\end{array}$ & $\begin{array}{l}\text { USA } \\
\text { USA }\end{array}$ \\
\hline 72 & $\begin{array}{c}\text { Mindfulness meditation and improvement in sleep quality and daytime } \\
\text { impairment among older adults with sleep disturbances: a randomized } \\
\text { clinical trial }\end{array}$ & 949 & JAMA Internal Medicine & David S. Black & USA \\
\hline 74 & $\begin{array}{l}\text { Preventing intrusive memories after trauma via a brief intervention } \\
\text { involving Tetris computer game play in the emergency department: a } \\
\text { proof-of-concept randomized controlled trial }\end{array}$ & 944 & Molecular Psychiatry & E. A. Holmes & Sweden \\
\hline 75 & $\begin{array}{c}\text { Cumulative use of strong anticholinergics and incident dementia: a } \\
\text { prospective cohort study }\end{array}$ & 942 & JAMA Internal Medicine & Shelly L. Gray & USA \\
\hline 76 & Sleep and human aging & 941 & Neuron & Matthew P. Walker & USA \\
\hline 77 & $\begin{array}{l}\text { A } 2 \text { year multidomain intervention of diet, exercise, cognitive training, and } \\
\text { vascular risk monitoring versus control to prevent cognitive decline in } \\
\text { at-risk elderly people (FINGER): a randomized controlled trial }\end{array}$ & 939 & The Lancet & Miia Kivipelto & Sweden \\
\hline 78 & Leisure activities and the risk of dementia in the elderly & 931 & $\begin{array}{l}\text { New England Journal of } \\
\text { Medicine }\end{array}$ & Joe Verghese & USA \\
\hline 78 & Urinary 8-oxo-7,8-dihydroguanosine as a potential biomarker of aging & 931 & Frontiers in Aging Neuroscience & $\begin{array}{l}\text { Lan-Lan Wang } \\
\text { Jian-Ping Cai }\end{array}$ & $\begin{array}{l}\text { China } \\
\text { China }\end{array}$ \\
\hline 80 & $\begin{array}{l}\text { Poor sleep is associated with CSF biomarkers of amyloid pathology in } \\
\text { cognitively normal adults }\end{array}$ & 930 & Neurology & Kate E. Sprecher & USA \\
\hline 81 & $\begin{array}{c}\text { Migraine and risk of cardiovascular disease in women: prospective } \\
\text { cohort study }\end{array}$ & 929 & British Medical Journal & Tobias Kurth & Germany \\
\hline 82 & Video gaming in school children: how much is enough? & 918 & Annals of Neurology & Jesus Pujol & Spain \\
\hline 83 & $\begin{array}{c}\text { Incidence of subarachnoid hemorrhage is decreasing together with } \\
\text { decreasing smoking rates }\end{array}$ & 913 & Neurology & Miikka Korja & Finland \\
\hline
\end{tabular}


Table 1. Cont

\begin{tabular}{|c|c|c|c|c|c|}
\hline Rank & Article Title & AAS & Journal & Corresponding Author & Country \\
\hline 84 & $\begin{array}{c}\text { Mild TBI and risk of Parkinson disease: A Chronic Effects of Neurotrauma } \\
\text { Consortium Study }\end{array}$ & 912 & Neurology & Raquel C. Gardner & USA \\
\hline 85 & $\begin{array}{c}\text { Sauna bathing reduces the risk of stroke in Finnish men and women: a } \\
\text { prospective cohort study }\end{array}$ & 911 & Neurology & Setor K. Kunutsor & UK \\
\hline 86 & Time trends in the incidence of Parkinson disease & 910 & JAMA Neurology & Walter A. Rocca & USA \\
\hline 86 & $\begin{array}{l}\text { A randomized controlled trial to test the effect of multispecies probiotics on } \\
\text { cognitive reactivity to sad mood }\end{array}$ & 910 & Brain, Behavior, \& Immunity & Laura Steenbergen & $\begin{array}{l}\text { The } \\
\text { Netherlands }\end{array}$ \\
\hline 88 & $\begin{array}{l}\text { Analgesic effects of alcohol: a systematic review and meta-analysis of } \\
\text { controlled experimental studies in healthy participants }\end{array}$ & 906 & Journal of Pain & Trevor Thompson & UK \\
\hline 89 & $\begin{array}{c}\text { Sleep loss promotes astrocytic phagocytosis and microglial activation in } \\
\text { mouse cerebral cortex }\end{array}$ & 905 & Journal of Neuroscience & Chiara Cirelli & USA \\
\hline 90 & $\begin{array}{l}\text { A qualitative impairment in face perception in Alzheimer's disease: } \\
\text { evidence from a reduced face inversion effect }\end{array}$ & 903 & Journal of Alzheimer's Disease & Sven Joubert & Canada \\
\hline 91 & $\begin{array}{c}\text { Acute and chronic effects of cannabinoids on effort-related decision-making } \\
\text { and reward learning: an evaluation of the cannabis 'amotivational' } \\
\text { hypotheses }\end{array}$ & 898 & Psychopharmacology & Will Lawn & UK \\
\hline 92 & Alcohol consumption and cognitive decline in early old age & 895 & Neurology & Séverine Sabia & UK \\
\hline 92 & Genetics and intelligence differences: five special findings & 895 & Molecular Psychiatry & R. Plomin & UK \\
\hline 94 & $\begin{array}{l}\text { Time to treatment with endovascular thrombectomy and outcomes from } \\
\text { ischemic stroke: a meta-analysis }\end{array}$ & 888 & $\begin{array}{l}\text { JAMA: Journal of the American } \\
\text { Medical Association }\end{array}$ & Michael D. Hill & Canada \\
\hline 95 & $\begin{array}{l}\text { Risk of pneumonia associated with incident benzodiazepine use among } \\
\text { community-dwelling adults with Alzheimer disease }\end{array}$ & 884 & $\begin{array}{l}\text { CMAJ: Canadian Medical } \\
\text { Association Journal }\end{array}$ & Heidi Taipale & Finland \\
\hline 95 & $\begin{array}{c}\text { Aerobic exercise and vascular cognitive impairment: a randomized } \\
\text { controlled trial }\end{array}$ & 884 & Neurology & Teresa Liu-Ambrose & Canada \\
\hline 97 & $\begin{array}{c}\text { Old brains come uncoupled in sleep: slow wave-spindle synchrony, brain } \\
\text { atrophy, and forgetting }\end{array}$ & 875 & Neuron & Randolph F. Helfrich & USA \\
\hline 98 & Neuroscience-inspired artificial intelligence & 873 & Neuron & Demis Hassabis & UK \\
\hline 98 & Seeing Jesus in toast: neural and behavioral correlates of face pareidolia & 873 & Cortex & $\begin{array}{l}\text { Jie Tian } \\
\text { Kang Lee }\end{array}$ & $\begin{array}{l}\text { China } \\
\text { Canada }\end{array}$ \\
\hline 100 & $\begin{array}{l}\text { The cumulative cost of additional wakefulness: dose-response effects on } \\
\text { neurobehavioral functions and sleep physiology from chronic sleep } \\
\text { restriction and total sleep deprivation }\end{array}$ & 868 & Sleep & Hans P.A. Van Dongen & USA \\
\hline
\end{tabular}


Table 2. Journals with top 100 articles, ranked according to the AAS.

\begin{tabular}{|c|c|c|c|}
\hline Rank & Journal Name & Number of Articles & Type of Access \\
\hline 1 & New England Journal of Medicine & 20 & S \\
\hline 2 & Neurology & 13 & S \\
\hline 3 & The Lancet & 7 & S \\
\hline 3 & Neuron & 7 & S \\
\hline 5 & British Medical Journal & 5 & S \\
\hline 6 & Nature Neuroscience & 4 & S \\
\hline 6 & JAMA Neurology & 4 & S \\
\hline 6 & JAMA Internal Medicine & 4 & S \\
\hline 9 & Molecular Psychiatry & 3 & S \\
\hline 9 & $\begin{array}{c}\text { JAMA: Journal of the American Medical } \\
\text { Association }\end{array}$ & 3 & S \\
\hline 11 & Stroke & 2 & S \\
\hline 11 & Sleep & 2 & S \\
\hline 11 & Psychopharmacology & 2 & S \\
\hline 11 & Journal of Alzheimer's Disease & 2 & S \\
\hline 11 & Frontiers in Aging Neuroscience & 2 & $\mathrm{OA}$ \\
\hline 11 & Acta Neuropathologica & 2 & S \\
\hline 18 & Neurobiology of Aging & 1 & S \\
\hline 18 & Journal of Psychopharmacology & 1 & S \\
\hline 18 & Alzheimer's Research \& Therapy & 1 & OA \\
\hline 18 & Brain & 1 & $\mathrm{~S}$ \\
\hline 18 & NeuroReport & 1 & $S$ \\
\hline 18 & $\begin{array}{c}\text { Journal of NeuroEngineering and } \\
\text { Rehabilitation }\end{array}$ & 1 & OA \\
\hline 18 & Alzheimer's \& Dementia & 1 & S \\
\hline 18 & Neuroscience \& Biobehavioral Reviews & 1 & S \\
\hline 18 & Social Cognitive \& Affective Neuroscience & 1 & $\mathrm{OA}$ \\
\hline 18 & Neuropsychology & 1 & $\mathrm{~S}$ \\
\hline 18 & $\begin{array}{c}\text { Journal of Neurology Neurosurgery \& } \\
\text { Psychiatry }\end{array}$ & 1 & S \\
\hline 18 & Lancet Neurology & 1 & S \\
\hline 18 & Annals of Neurology & 1 & S \\
\hline 18 & Brain Behavior \& Immunity & 1 & S \\
\hline 18 & Journal of Pain & 1 & S \\
\hline 18 & Cortex & 1 & S \\
\hline 18 & $\begin{array}{c}\text { CMAJ: Canadian Medical Association } \\
\text { Journal }\end{array}$ & 1 & S \\
\hline 18 & Journal of Neuroscience & 1 & S \\
\hline
\end{tabular}

Abbreviations: $\mathrm{S}=$ subscription, $\mathrm{OA}=$ open access.

Table 3. Journals with top 100 articles, ranked according to the country of the corresponding author.

\begin{tabular}{ccc}
\hline Rank & Country of the Corresponding Author & Number of Articles \\
\hline 1 & USA & 49 \\
2 & UK & 20 \\
3 & Canada & 7 \\
4 & The Netherlands & 4 \\
5 & Spain & 3 \\
6 & Germany & 3 \\
7 & Sweden & 3 \\
8 & France & 2 \\
9 & China & 2 \\
9 & Finland & 2 \\
11 & Slovenia & 1 \\
12 & Switzerland & 1 \\
13 & Brazil & 1 \\
14 & India & 1 \\
15 & Australia & 1 \\
\hline
\end{tabular}


Table 4. Numbers of articles with top 100 AASs according to neurology subspecialties.

\begin{tabular}{cc}
\hline Subspecialty & Number of Articles \\
\hline Degenerative disorders & 32 \\
Neuroscience & 23 \\
Stroke & 11 \\
Sleep & 6 \\
Infection & 6 \\
Trauma & 5 \\
Headache & 4 \\
Demyelinating disorders & 3 \\
Seizure & 2 \\
Neuromuscular disorders & 2 \\
Neuro-oncology & 2 \\
Toxicity & 1 \\
Pain & 1 \\
Movement & 1 \\
Genetics & 1 \\
\hline
\end{tabular}

Table 5. Numbers of articles with top 100 AASs according to subject categories.

\begin{tabular}{cc}
\hline Subject Category & Number of Articles \\
\hline Disease information & 29 \\
Lifestyle and disease & 27 \\
Science information & 19 \\
New or advanced treatments & 18 \\
Side effects of treatment & 7 \\
\hline
\end{tabular}

\section{Discussion}

This Altmetric analysis revealed the current status of social recognition and public attention regarding neurology and neurological disorders. This is the first trial to evaluate this subject based on the premise that the acquisition of information and learning behaviors will eventually change from before the era of easy internet accessibility. Of the various subspecialties in neurology, research into degenerative and cerebrovascular disorders receives the strongest interest from the general public. People are frequently exposed to journals in general and internal medicine and clinical neurology with high impact factors via the present environment of information flow. In addition to the topic of disease information, members of the general public pay considerable attention to the relationship between lifestyle and disease. The present results may be utilized when establishing policies or planning promotions for public health in neurology and neurological disorders.

With the global accessibility and the popularity of the internet and social media, the utility of Altmetric analysis has grown rapidly since the concept was first introduced in 2011 [11]. This trend is expected to continue, because, by 2020, the number of worldwide social media users is expected to reach 2.95 billion, or around one-third of the worldwide population [12].

The article with the highest AAS (=3873) was an invited editorial (in the form of a letter) written by the wife of a famous patient [13]. Despite not being a medical specialist, she provided a precise description of the disease course and the treatment of her husband, Robin Williams. According to both his disease course and pathological examination, he tragically ended his life due to severe neuropsychiatric symptoms from diffuse Lewy body disease. The subjects of most of the other top 10 ranked articles were related to environment and lifestyle and diseases, such as chronic trauma, alcohol, living environment, and nutrients [14-17].

About half of the top 100 ranked articles were related to clinical aspects of medical information, such as disease information (29 articles, $29 \%$ ), new or advanced treatments $(17 \%)$, and side effects of treatment (8\%). However, the other half of the articles focused on less academic subjects, with 27 articles 
(27\%) addressing the relationship between lifestyle and diseases, as exemplified above. Science information rather than specific disease diagnoses/treatments was the subject in 19 articles (e.g., newly demonstrated mechanisms of memory persistence, the mechanism of dreaming, and the genetics of intelligence) $[18,19]$.

Our list naturally included some diseases that give rise to social problems. One of these is the Zika virus and its neurological complications, such as microcephaly and Guillain-Barré syndrome [20,21]. Another issue is chronic traumatic encephalopathy, which is a major problem among Americans [14]. Many American parents are informed about this issue by studies of cognitive performance and chronic physical head trauma, especially for American football athletes. It can therefore be presumed that the results of Altmetric analysis that are of interest to the general public may change as new social issues develop.

Another distinct characteristic of our analysis is that the articles ranked highly in the Altmetric analysis appeared to use general terminology for disorders in their titles rather than specific disease entities; for example, "Alzheimer's disease" was less common than "dementia" and "cognitive or intellectual dysfunction/disorders." This finding implies that common and easy-to-understand terminology might be more acceptable to the general public.

\section{Conclusions}

It is reasonable to use traditional citation-based metrics to measure the impact of a scholarly article in the sense that citations indicate that new evidence has been built upon by the findings of a given paper. Altmetrics, on the other hand, appears to reflect public interest rather than the scientific merits of an article. It should be remembered that there can be considerable discordance between the expectations of academic and medical value among scholars and the attitudes of the general public.

Author Contributions: Y.K., J.S.B., and D.Y.Y. conceived and designed the study; Y.K., J.S.B., and D.Y.Y. collected the data; Y.K., J.S.B., J.-E.K., and S.-H.L. analyzed the data; Y.K. and J.S.B. drafted the manuscript; J.S.B. supervised the study; and Y.K., J.-E.K., D.Y.Y., S.-H.L., and J.S.B. critically revised the manuscript. All authors have read and agreed to the published version of the manuscript.

Funding: This work was supported by Basic Science Research Program through the National Research Foundation of Korea (NRF) funded by the Ministry of Education under grant number NRF-2017R1D1A1B03029672 and by the Ministry of Science and ICT (grant number NRF-2018R1C1B5086320) and was supported by a grand no. 2019-08 from the Kangdong Sacred Heart Hospital Fund.

Conflicts of Interest: The authors declared no potential conflict of interest with respect to the research, authorship, and/or publication of this article.

Ethics Approval: The present study did not involve human subjects and thus did not require approval from an institutional review board.

Availability of Data and Material: Data cannot be shared because there are embargoes on datasets. Anonymized data will be shared by request from any qualified investigators.

\section{References}

1. MacRoberts, M.H.; MacRoberts, B.R. Problems of citation analysis: A critical review. J. Am. Soc. Inf. Sci. 1989, 40, 342-349. [CrossRef]

2. Kim, J.E.; Kim, J.K.; Park, K.M.; Kim, Y.; Yoon, D.Y.; Bae, J.S. Top-100 cited articles on Guillain-Barre syndrome: A bibliometric analysis. J. Peripher. Nerv. Syst. 2016, 21, 329-338. [CrossRef] [PubMed]

3. Cline, R.J.; Haynes, K.M. Consumer health information seeking on the Internet: The state of the art. Health Educ. Res. 2001, 16, 671-692. [CrossRef] [PubMed]

4. Trueger, N.S.; Thoma, B.; Hsu, C.H.; Sullivan, D.; Peters, L.; Lin, M. The altmetric score: A new measure for article-level dissemination and impact. Ann. Emerg. Med. 2015, 66, 549-553. [CrossRef] [PubMed]

5. Ruan, Q.Z.; Chen, A.D.; Cohen, J.B.; Singhal, D.; Lin, S.J.; Lee, B.T. Alternative metrics of scholarly output: The relationship among altmetric score, Mendeley reader score, citations, and downloads in plastic and reconstructive surgery. Plast. Reconstr. Surg. 2018, 141, 801-809. [CrossRef] [PubMed] 
6. Delli, K.; Livas, C.; Spijkervet, F.K.L.; Vissink, A. Measuring the social impact of dental research: An insight into the most influential articles on the Web. Oral Dis. 2017, 23, 1155-1161. [CrossRef] [PubMed]

7. Peoples, B.K.; Midway, S.R.; Sackett, D.; Lynch, A.; Cooney, P.B. Twitter predicts citation rates of ecological research. PLoS ONE 2016, 11, e0166570. [CrossRef] [PubMed]

8. Amath, A.; Ambacher, K.; Leddy, J.J.; Wood, T.J.; Ramnanan, C.J. Comparing alternative and traditional dissemination metrics in medical education. Med. Educ. 2017, 51, 935-941. [CrossRef] [PubMed]

9. Ortega, J.L. Disciplinary differences of the impact of altmetric. FEMS Microbiol. Lett. 2018, 365. [CrossRef] [PubMed]

10. Von Elm, E.; Altman, D.G.; Egger, M.; Pocock, S.J.; Gøtzsche, P.C.; Vandenbroucke, J.P. The Strengthening the Reporting of Observational Studies in Epidemiology (STROBE) statement: Guidelines for reporting observational studies. Ann. Intern. Med. 2007, 147, 573-577. [CrossRef] [PubMed]

11. Brigham, T.J. An introduction to altmetrics. Med. Ref. Serv. Q. 2014, 33, 438-447. [CrossRef] [PubMed]

12. Statista, the Statistics Portal. Available online: https:/www.statista.com/topics/1164/social-networks/ (accessed on 30 January 2017).

13. Williams, S.S. The terrorist inside my husband's brain. Neurology 2016, 87, 1308-1311. [CrossRef] [PubMed]

14. Mez, J.; Daneshvar, D.H.; Kiernan, P.T.; Abdolmohammadi, B.; Alvarez, V.E.; Huber, B.R.; Alosco, M.L.; Solomon, T.M.; Nowinski, C.J.; McHale, L.; et al. Clinicopathological evaluation of chronic traumatic encephalopathy in players of American football. JAMA 2017, 318, 360-370. [CrossRef] [PubMed]

15. Morris, M.C.; Wang, Y.; Barnes, L.L.; Bennett, D.A.; Dawson-Hughes, B.; Booth, S.L. Nutrients and bioactives in green leafy vegetables and cognitive decline: Prospective study. Neurology 2018, 90, e214-e222. [CrossRef] [PubMed]

16. Chen, H.; Kwong, J.C.; Copes, R.; Tu, K.; Villeneuve, P.J.; van Donkelaar, A.; Hystad, P.; Martin, R.V.; Murray, B.J.; Jessiman, B.; et al. Living near major roads and the incidence of dementia, Parkinson's disease, and multiple sclerosis: A population-based cohort study. Lancet 2017, 389, 718-726. [CrossRef]

17. Topiwala, A.; Allan, C.L.; Valkanova, V.; Zsoldos, E.; Filippini, N.; Sexton, C.; Mahmood, A.; Fooks, P.; Singh-Manoux, A.; Mackay, C.E.; et al. Moderate alcohol consumption as risk factor for adverse brain outcomes and cognitive decline: Longitudinal cohort study. BMJ 2017, 357. [CrossRef] [PubMed]

18. Richards, B.A.; Frankland, P.W. The persistence and transience of memory. Neuron 2017, 94, 1071-1084. [CrossRef] [PubMed]

19. Siclari, F.; Baird, B.; Perogamvros, L.; Bernardi, G.; LaRocque, J.J.; Riedner, B.; Boly, M.; Postle, B.R.; Tononi, G. The neural correlates of dreaming. Nat. Neurosci. 2017, 20, 872-878. [CrossRef]

20. Mlakar, J.; Korva, M.; Tul, N.; Popovic, M.; Poljsak-Prijatelj, M.; Mraz, J.; Kolenc, M.; Resman Rus, K.; Vesnaver Vipotnik, T.; Fabjan Vodusek, V.; et al. Zika virus associated with microcephaly. N. Engl. J. Med. 2016, 374, 951-958. [CrossRef] [PubMed]

21. Cao-Lormeau, V.M.; Blake, A.; Mons, S.; Lastere, S.; Roche, C.; Vanhomwegen, J.; Dub, T.; Baudouin, L.; Teissier, A.; Larre, P.; et al. Guillain-Barre Syndrome outbreak associated with Zika virus infection in French Polynesia: A case-control study. Lancet 2016, 387, 1531-1539. [CrossRef]

(C) 2020 by the authors. Licensee MDPI, Basel, Switzerland. This article is an open access article distributed under the terms and conditions of the Creative Commons Attribution (CC BY) license (http://creativecommons.org/licenses/by/4.0/). 